\title{
ETIKA DAN PERILAKU BIROKRASI DALAM MENDUKUNG PENGUATAN GOOD GOVERNANCE
}

\author{
Iwan Satibi \\ Ediyanto \\ Universitas Pasundan Bandung \\ iwan.satibi71@gmail.com
}

\begin{abstract}
Abstrak
Etika dan perilaku birokrat adalah aspek penting dalam pelaksanaan fungsi tata kelola yang baik. Penelitian ini bertujuan untuk menguji dan mengetahui apakah etika dan perilaku aparatur benar-benar mampu memberikan penguatan pada penerapan tata kelola yang baik. Metode yang digunakan dalam penulisan ini adalah metode deskriptif dengan analisis studi pustaka, yaitu studi tentang deskripsi teori, konsep, atau hasil penelitian yang terkait dengan fokus penelitian. Hasil penelitian menunjukkan bahwa etika dan perilaku birokrat berperan dalam membentuk nilainilai birokrasi dan dapat memperkuat konsep pemerintahan dalam pemerintahan.
\end{abstract}

Kata kunci: etika, perilaku birokrasi, tata kelola yang baik

\section{Abstract}

Bureaucrats' ethics and behavior are important aspects in referring to the implementation of good governance functions. This study aims to examine and find out whether the ethics and behavior of the apparatus is really able to provide reinforcement to the implementation of good governance. The method used in this paper is Descriptive Method with desk study study analysis, which is a study of the description of theories, concepts, or research results related to the focus of the study. The results showed that the ethics and behavior of bureaucrats play a role in shaping bureaucratic values and can strengthen the concept of governance in a government.

Keywords: ethics, bureaucratic behavior, good governance 


\section{PENDAHULUAN}

Persoalan etika dan perilaku birokrat belakangan ini semakin menarik perhatian berbagai kalangan. Menguatnya perhatian tersebut, sesungguhnya didasari oleh semakin maraknya fenomena yang mencerminkan buruknya etika dan perilaku aparatur dalam menjalankan tugas dan fungsinya sebagai pelayan publik. Merebaknya kasus korupsi, penyalahgunaan wewenang dan sejumlah penyimpangan perilaku diberbagai level pemerintahan (baca: pusat dan daerah) mencerminkan, betapa etika dan perilaku paratur pemerintah hingga saat ini masih memprihatinkan sehinggamembutuhkan penataan dan perbaikan.

Upaya untuk menata dan memperbaiki etika dan perilaku aparatur (baca: birokrat) di lingkungan birokrasi pemerintahan, sesungguhnya telah dilakukan baik terkait dengan penataan regulasi (peraturan) maupun pembentukan kelembagaan yang menangani masalah kode etik aparatur pemerintah. Masalahnya kemudian, mengapa etika dan perilaku aparatur tersebut justru semakin memperlihatkan performance yang tidak sejalan dengan keinginan dan kehendak masyarakat. Bahkan untuk kasus-kasus tertentu, perilaku aparatur ini justru lebih sering melukai perasaan dan hati nurani rakyat.

Etika dalam tulisan ini, dimaknai secara luas sebagai nilai-nilai ideal yang seharusnya dijadikan dasar dalam penyelenggaraan urusan publik. Berkaitan dengan aspek-aspek perilaku yang baik seperti akuntabel, responsif, transparan, bebas KKN, netral, tidak diskriminatif, sopan, dan nilai-nilai lainnya. Nilai ini yang akan menjadi pedoman bagi pejabat pemerintah (birokrat) dalam menjalankan tugas, sehingga dapat terkendali dan terlindungi dari nilai nilai yg tidak sesuai dengan nilai organisasi, karena etika pribadi akan mempengaruhi nilai nilai dalam berorganisasi. Dikuatkan oleh Levine, Peters dan Thompson (1990:191) dengan argumen bahwa aparat birokrasi publik adalah orang-orang yang memiliki kelemahan layaknya individu lain di luar birokrasi.

Terselenggaranya tata kelola pemerintahan yang baik atau yang dikenal

dengan istilah "good governance" merupakan 'impian' sekaligus harapan semua 
bangsa di dunia. Pandangan tersebut dapat dimengerti karena melalui pelaksanaan good governance, upaya penciptaan aparatur pemerintah yang bersih dan bebas dari tindakan yang tidak terpuji serta tidak berpihak pada kepentingan masyarakat diharapkan dapat diwujudkan secara nyata. Selain itu, pelaksanaan good governance juga akan bersentuhan atau berkaitan dengan upaya untuk meningkatkan kinerja birokrasi pemerintah yang kemudian berujung pada peningkatan kualitas pelayanan publik. Oleh sebab itu, pelaksanaan good governance sudah selayaknya menjadi komitmen semua untuk mewujudkannya.

Namun demikian, harus diakui bahwa melaksanakan konsep good governance secara konsisten dan berkelanjutan memang tidah semudah membalikan tangan. Berbagai tantangan, kendala serta godaan senantiasa datang silih berganti, baik dari kalangan internal maupun eksternal. Djuaeni (2015) menyebutkan tantangan penerapan Good Governance di Indonesia, yaitu terjadinya krisis multidimensi, yang bersifat vicious crises, yang meliputi krisis moral, krisis hukum, krisis moneter, krisis ekonomi, krisis kepercayaan, krisis politik dan krisis kemanusiaan.

Walaupun disadari benar bahwa esensi pelaksanaan good governance tersebut diarahkan untuk meningkatkan kualitas pelayanan dan kesejahteraan masyarakat. Rendahnya kepedulian, sikap masa bodoh serta buruknya performance aparatur terhadap masyarakat yang dilayani, boleh jadi merupakan cermin gagalnya pelaksanaan good governance di lingkungan birokrasi pemerintahan. Kondisi seperti ini seringkali diperparah oleh ketidakjelasan penyelenggaraan pelayanan publik yang semestinya diatur melalui regulasi (peraturan) yang jelas serta memiliki legitimasi kuat, baik menyangkut lamanya waktu, besarnya anggaran maupun prosedur lainnya. Dampaknya terjadi ketidakseimbangan antara hak yang harus diterima oleh masyarakat (pengguna jasa layanan) dengan kewajiban yang diberikan oleh aparat. Sehingga kecenderungan yang muncul adalah bahwa kewajiban yang harus diberikan (dikeluarkan) oleh masyarakat justru berbanding terbalik dengan hak yang mereka terima. Aparatur pemerintahjusteru semakin leluasa mempermainkan kekuasaannya 
atas nama prosedur atau peraturan sesuai dengan kepentingannya, sementara masyarakat yang dilayani semakin lemah dan tidak berdaya.

Kenyataan lain yang menguatkan terjadinya fenomena ini adalah seringnya petugas layanan yang mengabaikan pelayanan publik, karena mereka lebih "tergoda" oleh tugas-tugas "terselubung” yang secara finansial dianggap lebih menguntungkan, padahal cukup menyita waktu yang banyak. Dampaknya, tugas pokok yang menjadi tanggunggung jawabnya menjadi terhambat dan masyarakat terpaksa harus menerima resiko untuk mendapatkan pelayanan yang tidak jelas waktunya.

Berbagai fenomena di atas mengisyaratkan bahwa pergeseran paradigma sistem pemerintahan saat ini, baru sebatas wacana dan retorika belaka. Perubahan sistem, struktur dan kultur birokrasi pemerintahan yang merupakan esensi dari pelaksanaan good governance, justru lebih banyak diperdebatkan di ruang-ruang seminar atau dunia akademik, sementara pelaku utama yakni aparatur pemerintah lebih terkesan masih jalan di tempat. Bahkan dalam kasus tertentu, perubahan yang akan dilakukan seringkali mendapatkan hambatan atau perlawanan dari pihak-pihak yang merasa dirugikan, baik di lingkungan internal maupun eksternal. Oleh karena itu, dapat dimengerti apabila reformasi birokrasi yang dilakukan oleh pemerintah, baik di tingkat pusat maupun daerah lebih kental nuansa politisnya ketimbang dilandasi oleh kebutuhan dan tuntutan organisasi.

Kenyataan ini jelas merupakan suatu bukti bahwa upaya penyelenggaraan pemerintahan yang baik (good governance) hingga saat ini memang belum dapat dilaksanakan secara efektif.

Lantas, apa sebenarnya esensi etika dan perilaku aparatur tersebut? Mengapa etika dan perilaku apartur ini harus dikuatkan dalam konteks pelaksanaan peran dan fungsinya sebagai pelayan publik? Kemudian, benarkah etika dan perilaku aparatur ini mampu memberikan penguatan terhadap pelaksanaan good governance? Berbagai pertanyaan itulah yang mengilhami hadirnya tulisan ini.Dalam tulisan ini akan dikupas bagaimana etika dan perilaku birokrasi dapat memperkuat tata kelola 
pemerintahan atau yang disebut dengan konsep good governance dalam sebuah tatanan negara.

Sesuai dengan konteks topik di atas, maka metode kajian yang akan digunakan adalah metode deskriptif. Penggunaan metode deskriptif didasarkan pada pertimbangan bahwa metode deskriptif digunakan untuk menggambarkan suatu kondisi/gejala, sistem, peristiwa (seseorang, kelompok orang, lembaga/institusi, masyarakat saat ini berdasarkan data dan informasi yang tersedia.Sedangkan analisis kajian yang dilakukan menggunakan desk study, yakni kajian terhadap jabaran teori, konsep, atau hasil-hasil penelitian yang berhubungan dengan fokus kajian yang akan dilakukan. Kajian pustaka mempunyai dua tujuan, yaitu tujuan utama dan tujuan lain. Tujuan utamanya yaitu membantu peneliti dalam memecahkan masalah penelitiannya, sedangkan tujuan lainnya adalah memperoleh gambaran tentang kedudukan penelitiannya terhadap penelitian-penelitian lain.

\section{PEMBAHASAN}

\section{Konsep Etika Birokrasi}

Secara etimologis, etika berasal dari bahasa Yunani "Ethos" yang berarti watak kesusilaan atau adat. Widjaja, 2003 menjelaskan istilah etika (ethics) dalam bahasa Latin disebut "ethicus" yang berarti adat, kebiasaan, atau kesediaan jiwa akan kesusilaan. Sangat identik dengan kata moral yang juga berarti adat atau cara hidup. Lebih lanjut Widjaja menggambarkan bahwa sebagai cabang filsafat, etika mempelajari pandangan-pandangan persoalan-persoalan yang berhubungan dengan masalah kesusilaan, atau sebagai penyelidikan filsofis mengenai kewajibankewajiban manusia, dan hal-hal yang baik dan buruk. Sedangkan Kumorotomo (2013: 6-7) mendefinisikan etika sebagai kebiasaan atau watak, sedangkan moral berarti cara hidup atau kebiasaan. Poedjawijata dalam Pasolong (2010: 190) mengatakan bahwa etika merupakan cabang filsafat yang mencari kebenaran yang sedalamdalamnya, mencari ukuran baik buruknya tingkah laku manusia. Sementara

Istilah birokrasi (bureaucracy) berasal dari bahasa Yunani "bureu" yang berarti 
kantor, dan "kratia" (cracein)yang berarti pemerintahan. Jadi, birokrasi berarti pemerintahan melalui kantor atau "government by bureau" (Kumorotomo, 2000).

Chandler \& Plano dalam Pasolong (2010: 193) mengemukakan empat aliran utama etika, yaitu empirical theory, bahwa etika diturunkan dari pengalaman manusia dan persetujuan umum, rational theory, bahwa baik atau buruk sangat tergantung dari alasan dan logika yang melatarbelakangi suatu perbuatan, bukan pengalaman, intuitive theory, bahwa etika tidak harus berasal dari pengalaman dan logika, tetapi dari diri manusia secara alamiah yang memiliki pemahaman tentang apa yang benar dan salah, baik dan buruk, dan relevation theory, bahwa yang benar dan salah berasal dari kekuasaan di atas manusia yaitu Tuhan Yang Maha Esa, yang menjadi rujukan utama untuk memutuskan apa yang benar dan apa yang salah.

Terdapat empat jenis etika dalam berinteraksi, yakni etika individual atau moralitas personal, etika profesi, etika organisasi, dan etika sosial (Shafritz dan Russell 1997:607), dimana dalam prakteknya empat jenis etika tersebut tidak selalu berjalan seiringan. Misalnya, nepotisme atau favoritisme dalam pelayanan publik adalah bentuk pelanggaran etika profesi maupun etika organisasi, tetapi dari sisi etika sosial bisa dibenarkan. Hal inilah yang menjadikan etika sebagai isu yang kompleks dan sarat akan pertentangan nilai, sehingga membutuhkan pendekatan yang hati-hati. (Gow, 2005).

\section{Konsep Perilaku Birokrasi}

Perilaku birokrasi pada hakekatnya merupakan hasil interaksi birokrasi sebagai kumpulan individu dengan lingkungannya (Thoha, 2005:138). Konsep perilaku organisasi menurut Robbins (2008:11) adalah perilaku organisasi sebagai bidang studi yang menyelidiki pengaruh yang dimiliki individu, kelompok, dan struktur terhadap perilaku dalam organisasi, yang bertujuan menerapkan ilmu pengetahuan semacam ini guna meningkatkan keefektifan suatu organisasi. Perilaku dipengaruhi berbagai faktor, baik internal maupun external, Ndraha (1997: 36) menjelaskan faktor faktor terseut ialah adanya kemampuan, 
kebutuhan, cara berpikir untuk menentukan pilihan, pengalaman dan reaksi terhadap sesuatu.

Untuk memahami dan menelaah prilaku aparatur dalam suatu organisasi, dalam hal ini birokrasi, hal itu dapat dipelajari melalui dimensi struktural organisasinya, Daft dan Steers (1986:217) menjelaskan bahwa teori organisasi merupakan cara berpikir tentang organisasi yang berdasarkan pola dan peraturan dalam desain organisasi dan prilaku manusianya. Desain organisasi berhubungan dengan proses operasional untuk menciptakan struktur tugas dan wewenang yang akan menjadi ciri aktivitas anggotanya.

Perilaku birokrasi dapat tercermin pada perilaku manusia (birokrat), dimana seperangkat perbuatan individu menjelma menjadi perilaku kelompok, dan akhirnya menjadi representasi perilaku organisasi yang kemudian dimaknai sebagai perilaku birokrasi. (hamzah, 2014). Sebagaimana diungkapkan oleh Ndraha (2003:521) bahwa perilaku birokrasi terbentuk dari interaksi antara karakteristik individu, dan karakteristik birokrasi (organisasi) atau lebih spesifik lagi antara struktur dan aktor (pejabat).

\section{Konsep Good Governance}

Istilah 'good governance' di Indonesia kembali mengemuka sejalan dengan merebaknya arus reformasi yang dimotori oleh kalangan mahasiswa dan kaum intelektual.Konsep tersebut kemudian merambah keberbagai dimensi kehidupan, termasuk di kalangan aparatur negara yang dianggap sebagai ujung tombak dari pelaksanaan pemerintahan.Wancana tersebut kemudian menjadi sangat menarik untuk dicermati ketika persoalan krisis bangsa: seperti merebaknya kasus korupsi, terpuruknya ekonomi, rendahnya kinerja aparatur, buruknya layanan publik, ketimpangan sosial yang semakin menganga, fenomena kemiskinan yang semakin merata, serta krisis politik yang berkepanjangan dianggap sebagai persoalan nasional yang urgen untuk diselesaikan. Lalu, apakah good governance itu? 
Menurut Ganie \& Rochman (2000: 142) governance diterjemahkan sebagai "mekanisme pengelolaan sumber daya ekonomi dan sosial yang melibatkan pengaruh sektor negara dan sektor non pemerintah dalam suatu kegiatan kolektif'. Sedangkan Pinto dalam Nisjar (1997 :119) mengartikan governance sebagai "praktek penyelenggaraan kekuasaan dan kewenangan oleh pemerintah dalam pengelolaan urusan pemerintahan secara umum dan pembangunan ekonomi pada khususnya". Sejalan dengan pengertian tersebut, LAN RI (2000: 5) mengartikan governance sebagai "proses penyelenggaraan kekuasaan negara dalam melaksanakan penyediaan public goods and service". Pengertian yang lebih spesifik dikemukakan oleh UNDP (1996) yang menterjemahkan good governance sebagai berikut: "governance can be seen as the exercise of outhority to manage all aspects of a country's affairat all levels in all spheres(public, private, civil) it comprisesthe mechanisms, proces.

Berbagai pengertian di atas mengisyaratkan bahwa konsep good governance sesungguhnya sangat berkaitan dengan penyelenggaraan kekuasaan dan kewenangan negara baik dalam sektor ekonomi, sosial, pelayanan publik, maupun layanan privat (pribadi). Kemudian secara fungsional pelaksanaan good governance tidak hanya melibatkan sektor pemerintah semata, tetapi juga melibatkan masyarakat dan swasta.

Tantangan bagi semua masyarakat dewasa ini adalah bagaimana mewujudkan sistem governance yang mampu merealisasikan terwujudnya kemakmuran semua orang serta mengantisipasi dampak negatif dari perbuatan korupsi yang diduga kuat melibatkan sejumlah pejabat negara, baik di tingkat pusat maupun daerah. Urgensi untuk mewujudkan good governance bukan hanya dipandang cocok untuk mengatasi kemiskinan dan ketimpangan, tetapi juga sangat relevan dengan kebutuhan untuk proses pemulihan, stabilitas ekonomi dan krisis politik yang kian memburuk serta rendahnya kinerja dan pelayanan publik. Itulah sebabnya, dalam pelaksanaan good governance pemerintah tidak bisa berjalan sendiri, tetapi harus melibatkan berbagai pihak, baik masyarakat maupun kalangan swasta.Pendapat tersebut sejalan dengan pandangan Taschereau dan Compos (UNDP, 1997) juga menyatakan bahwa "Tata kepemerintahan yang baikmerupakan suatu kondisi yang menjamin adanya proses 
kesejajaran, kesamaan, kohesi dan keseimbangan peran, serta adanya saling mengontrol yang dilakukan oleh tiga komponen, yaitu Government, Civil Society, dan Business".

Thoha (2000) menggaris bawahi bahwa prinsip demokratis yang melekat pada good governance meletakan urgensi untuk menempatkan ekuasaan ditangan rakyat bukan ditangan penguasa. Kemudian, tidak adanya rasa takut untuk memasuki suatu perkumpulan atau serikat sesuai dengan kebutuhan hati nurani, dan terakhir dihargainya moral perbedaan pendapat.

Sejalan dengan pemikiran, Riyaas Rasyid dan Mostopadidjaja (2002) menempatkan aparatur pemerintah sebagai ujung tombak penyelenggaraan good governance yang bersih dari KKN tampaknya perlu juga ditelusuri sampai sejauh mana bahaya perbuatan kolusi, korupsi dan nepotisme bagi kehidupan berbangsa dan bernegara. Hal ini sangat penting untuk dikaji mengingat perbuatan tersebut sangat inheren dengan perilaku aparatur itu sendiri.

Sejalan dengan pandangan di atas, UNDP (1996) mengemukakan tiga unsur utama (domains) yang perlu dilibatkan dalam penyelenggaraan kepemerintahan yang baik (good governance), yakni the state (Negara), the private sector (sektor swasta), dan civil societyorganizations (organisasi kemasyarakatan). Untuk melukiskan hubungan antar sektor dalam proses pelaksanaan good governance dapat dijelaskan dalam gambar sebagai berikut:

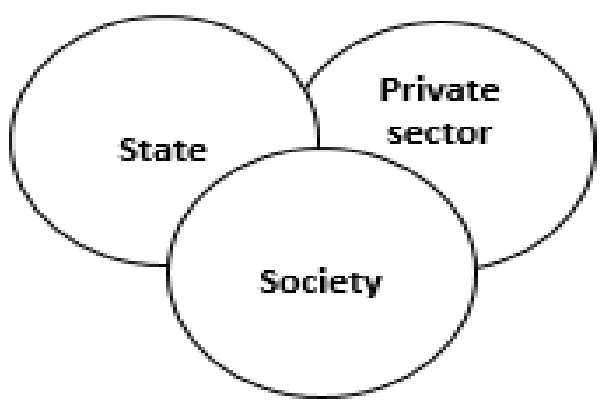

Gambar 1: Hubungan Antar Sektor 
Dapat dikatakan bahwa good governance merupakan sistem yang memungkinkan terjadinya mekanisme penyelenggaraan pemerintahan negara yang efisien dan efektif dengan menjaga sinergi yang konstruktif diantara pemerintah, sektor swasta, dan masyarakat.

Pelaksanaan good governance bukanlah suatu proses yang sederhana, tetapi membutuhkan adanya komitmen dan sejumlah ketentuan yang dapat dijadikan sebagai pedoman atau landasan bagi semua pihak yang terlibat (stake holders), khususnya pemerintah. Untuk itu, pemahaman yang komprehensif terhadap karakteristik good governance tampaknya tidak bisa ditawar-tawar lagi. Sejalan dengan hal tersebut, UNDP (1997) telah mengisyaratkan bahwa sebuah governance disebut 'good' bila mempunyai beberapa karakteristik, yaitu Partisipatif, Rule of law, Responsif, Berorientasi pada konsensus ,Equity,Efektif, dan Efisien, Akuntable,Bervisi strategis,Legitimasi, Resaurces prudence,Empowering dan Enabling, Serta Kemitraan dan Berorientasi pada masyarakat.

Untuk mempertajam pemahaman tentang karateristik good governance di atas, Mustopadidjadja AR (1999) dan Riyas Rasyid (2000) merekomendasikan 6 (enam) karakteristik good governance yang harus menjadiacuan dalam mengarahkan kebijakan sistem pemerintahan yaitu pertama, adanya kepastian hukum, keterbukaan, profesional dan memiliki akuntabilitas, meliputi penciptaan sistem hukum yang benar dan adil dalam lingkup hukum nasional (dalam keseluruhan tatanan administrasi pemerintahan), hukum adat dan hukum kemasyarakatan, pemberdayaan pranata hukum, desentralisasi dan penyusunan peraturan perundangundangan serta pengawasan masyarakat yang dilakukan oleh DPR. Kedua,prinsip keterbukaan yang meliputi penumbuhan iklim yang kondusif bagi terlaksananya pengakuan terhadap hak asasi manusia, transparansi informasi secara benar, jujur dan adil. Ketiga,prinsip akuntabilitas, meliputi kejelasan rencana kerja, prosedur dan mekanisme kerja, dengan sistem pertanggungjawaban yang jelas serta pemberlakuan sistem pemberian ganjaran dan sanksi yang konsisten, dapat meningkatkan 
pemberdayaan masyarakat dan mengutamakan pelayanan prima kepada masyarakat tanpa diskriminasi. Keempat, prinsip profesionalitas yang meliputi kapabilitas, kompetensi dan integritas. Artinya mampu mengakomodasi kontrol sosial masyarakat. Kelima, partisipasi, otoaktivitas dan desentralisasi sebagai wujud komitmen terhadap nilai-nilai kemanusiaan dan demokrasi, dan keenam berkembangnya sistem checks and balances, dari dan dalam keseluruhan unsur penyelenggara negara, sehinggaterwujud good governance.

\section{Etika dan Perilaku Birokrasi dalam Penguatan Good Governance}

Dalam dunia administrasi publik atau birokrasi, etika bermakna sebagai filsafat dan "professional standards" (kode etik atau etika jabatan), atau moral atau "right rules of conduct" (aturan berperilaku yang benar) yang harus dipatuhi oleh administrator publik atau aparat birokrasi atau pemberi pelayanan publik. (Denhard dalam Keban, 2008). Djaja (2012) menegaskan kembali bahwa etika dalam birokrasi publik (etika pejabat publik) berkenaan dengan perbuatan seseorang yang memegang jabatan tertentu, baik dalam waktu kerja maupun di luar kerja dan dalam kehidupannya sehari-hari.

Dalam kaitannya dengan birokrasi pemerintahan, berkembang berbagai cara pandang yang pada intinya membedakan etika ke dalam dua perspektif utama, yakni perspektif kultural dan perspektif struktural (Quill 2008; Carr 1999; Levine, Peters dan Thompson 1990:191).

Sebagaimana telah dijelaskan di atas, bahwa untuk mewujudkan pelaksanaan good governance secara konsisten dan sustainable (berkelanjutan) bukanlah pekerjaan yang mudah, apalagi good governance tersebut diarahkan pada upaya penciptaan aparatur yang bersih dan berwibawa. Untuk itu, jajaran birokrasi pemerintahan harus memahami esensi birokrasi itu sendiri dikaitkan dengan penciptaan good governance yang dimaksud.

Dalam konteks ini David Obsorne dan Gaebler (1992) menyampaikan sepuluh konsep birokrasi yaitu: 
(1) Catalytic government: Steering rather than rowing. Aparatur dan birokrasi berperan sebagai katalisator, yang cukup hanya mengendalikan sumbersumberyang ada di masyarakat. Dengan demikian aparatur dan birokrasi harus mampumengoptimalkanpenggunaan dana dan daya sesuai dengan kepentingan publik.(2) Community-owned government: empower communities to solve their own problems, rather than marely deliver services. Aparatur dan birokrasi harus memberdayakan masyarakatdalam pemberian pelayanannya. (3) Competitive government: promote and encourrage Competition, rather than monopolies". Aparatur dan birokrasi harus menciptakan persaingandalam setiap pelayanan. (4) Misssion-driven government: be driven by mission, rather than rules". Aparatur dan birokrasi harus melakukan aktivitas yang menekankan kepada pencapaian apa yang merupakan "misinya" dari pada menekankanpada peraturan-peraturan. (5) Result-oriented government: result oriented by fundingoutcomes rather than inputs. Aparatur dan birokrasi berorientasi kepada kinerja yang baik. Instansi yang demikian harus diberi kesempatan yang lebih besardibanding instansi yang kinerjanya kurang.(6) Customer-driver government: meet theneeds ofthe customer retherthan the bureaucracy. Aparatur dan birokrasi mengutamakan pemenuhan kebutuhan masyarakatbukan kebutuhan dirinya sendiri.(7) Enterprising government: concentrate on earning money rather than just speding it. Aparaturbirokrasi harus memiliki aparatyang tahu carayang tepat dengan menghasilkanuang untuk organisasinya, disamping pandai menghemat biaya.(8)Anticipatory government: invest in preventing problems rather than curing crises. Aparatur dan birokrasi yang antisipatif. Lebih baik mencegah daripada menanggulangi. Menciptakan 'mental swich' dalam aparat daerah.(9) Decentralilazed government:decentralized authority rather than build hierarcy. Diperlukan desentralisasidalam pengelolaan pemerintahan, dari berorientasi hirarki menjadi partisipatif dengan pengembangan kerjasama tim. Dan terakhir (10)Market-oriented government: solve problemby influencing market forces ratherthan by treating publicprograms. Aparatur dan birokrasi harus memperhatikan kekuatan pasar sehingga kebijakan harus berdasarkanpada kebutuhan pasar.

Dari kesepuluh prinsip tersebut sebenarnya ada tiga konsep utama yang sangat mungkin untuk diadopsi dan dikembangkan di Indonesia, agar proses transformasi aparatur dan birokrasi kinerjanya semakin menuju kepada merit system, birokrasi pemerintahan yang representative dan accountable. Yaitu Customer-driver government: meet the needs of the customer rether than the bureaucracy, Decentralilazed government: decentralized authority rather than build hierarcy, Result-oriented government: result oriented by funding outcomes rather than inputs. 
Melengkapi konsep di atas, Gaebler dan Plastrik (1997) menyampaikan lima strategi untuk pengembangan konsep Reinventing Government yang dikenal dengan istilah "The Five C'S", yaitu:

(1) strategi inti (Core Strategi), yaitu trategi merumuskan kembali tujuantujuan penyelenggaraan pemerintahan, termasuk otonomi daerah melalui penetapan visi, misi, tujuan dan sasaran, arah kebijakan serta peran-peran kelembagaan serta individu aparatur penyelenggara pemerintahan.(2) Strategi konsekuensi (Consequency Strategi), dalam hal ini perlu dirumuskan dan ditata kembali pola-pola insentif kelembagaan maupun individual, baik melalui pendekatanmanajemen kompetitif, manajemen bisnis (komporatisasidan privatisasi), atau manajemen kinerja (performance management). (3) Strategi pemakai jasa (Customer Strategi) aparatur birokrasi dalam hal ini perlu melakukan reorientasi dari kepentingan politik pemerintahan, serta orientasipada kepentingan kelembagaannya, kearah kepentinganpemenuhan kebutuhan berdasarkan pilihan-pilihan masyarakat (pemakai jasa publik), peningkatan kualitas layanan, serta kompetisi pasar yang sehat. (4) Strategi pengendalian (Control Strategy), yaitu adanya perumusan kembali dalam upaya pengendalian organisasi, mulai dari pengendalian strategis yang merupakan proses perumusan dan penetapan organisasi, pengendalian manajemen, yang merupakan pengendalian dalam menjaga agar pelaksanaan tugas (actuating) sesuai dengan strategi yang telah ditetapkan, pengendalian tugas sebagai pengendalian yang sifatnya pelaksanaan (operational). Ketiga pengendalian ini bisa dikembangkan melalui pengembangan struktur organisasi kelembagaan yang bertumpu pada kekuatan aparatur seperti gugus kendali mutu (Total quality control). Dan strategi terakhir (5) adalah strategi budaya/kultur (Cultur Strategy), yaitu adanya upaya reorientasi perilaku dan budaya aparatur serta birokrasi yang lebih terbuka dan mampu merevitalisasi dan mengadopsi nilai-nilai budaya (baik budaya lama maupun baru), yang lebih menyentuh niali-nilai keadilan dan hati nurani.

Agar lembaga pemerintah lebih mampu melaksanakan fungsi kepemerintahan yang baik (good governance), perlu diciptakan suatu sistem birokrasi dengan ciri-ciri sebagai berikut:

1) Memiliki struktur yang sederhana, dengan sumberdaya manusia yang memiliki kompetensi melaksanakan tugas-tugas kepemerintahan(pengembangan kebijakan dan pelayanan) secara arif, efisien dan efektif. 
2) Mengembangkan hubungan kemitraan (Partnership) antara pemerintah dengan setiap unsur dalam masyarakat yang bersangkutan (tidak sekedar kemitraan internal diantara sesama jajaran instansi pemerintahan saja).

3) Memahami dan komit akan manfaat dan arti pentingnya tanggung jawab bersama dan kerjasama dalam suatu keterpaduan serta sinergisme dalam pencapaian tujuan.

4) Adanya dukungan dan sistem imbalan yang memadai untuk mendorong terciptanya motivasi, kemampuan dan keberanian menanggung resiko (risk taking) bernisiatif, partisipatif, yang telah diperhitungkan secara realistik dan rasional.

5) Adanya kepatuhan dan ketaatan terhadap nilai-nilai internal (kode etik) administrasi publik, juga terhadap nilai-nilai etika dan moralitas yang diakui dan dijunjung tinggi secara bersama-sama dengan masyarakat yang dilayani. Adanya pelayanan administrasi public yang berorientasi kepada masyarakat yang dilayani (client centered) inklusif (mencermikan layanan yang mencakup secara merata seluruh masyarakat bangsa yang bersangkutan, tanpa ada perkecualian); administrasi pelayanan publik yang mudah dijangkau (accessible) masyarakat dan bersifat bersahabat (user friendly); berasaskan pemerataan yang berkeadilan(equitable) dalam setiap tindakan dan layanan yang diberikan kepada masyarakat; mencerminkan wajah pemerintah yang sebenarnya (tidak bermuka dua) atau tidak menerapkan standar ganda (double standards) dalam menentukan kebijakan dan memberikan layanan terhadap masyarakat; berfokus pada kepentingan masyarakat dan bukannya kepentingan internal organisasi pemerintah (outwardly focused); bersikap profesional dan bersikap tidak memihak (non-partisan). 


\section{KESIMPULAN}

Tulisan ini telah membahas dan mendiskusikan tentang akar persoalan masalah etika dan perilaku birokrasi dan peranannya dalam mendukung penguatan good governance. Maka kesimpulan yang dapat diambil dari hasil pembahasan pada tulisan ini adalah sebagai berikut:

1. Etika birokrat sangat menentukan warna dari birokrasi suatu organisasi. Pelaksanaan good governance sangat dipengaruhi oleh etika birokrasi yang terdapat dalam organisasi tersebut.

2. Perilaku birokrat sangat mempengaruhi pelaksnaan good governance dalam suatu organisasi.

3. Penguatan good governance dapat dilakukan dengan penguatan unsur etika dan perilaku birokrat dalam prinsip prinsip good governance.

\section{DAFTAR PUSTAKA}

Daft, Richard L and Steers, Richard M, Organization: A Micro-Macro Approach (Glenview, III, Scott, Foresman and Co., 1986, (hal 217).

David Obsorn and Ted Gabler, 1992, Reiventing Government: How the Enterpreneurrial Spirit is Transforming ThePublic Sector, Addison-Wesley publishing Co. Inc. Massachusette, USA.

Djadja, Saefullah, 2012, Pemikiran Kontemporer Administrasi Publik: Perspektif Manajemen Sumberdaya Manusia Dalam Era Desentralisasi, Bandung, LP3N FISIP UNPAD.

Djuaeni, Ach. K, Tantangan Penerapan Good Governance di Indonesia, 2015, Jurnal Inspirasi, Volume 6 No. 2: 32-36 
Ganie-Rochman, Meuthia.2000. Artikel “Good Governance: Prinsip, Komponen dan Penerapannya", dalam HAM : Penyelenggaraan Negara Yang Baik dan Masyarakat Warga, Jakarta : KOMNAS HAM.

Gow, J.I. 2005. A Practical Basis for Public Service Ethics. Paper pada the Annual Conference of the Canadian Political Science Association Western University, London Ontario, June 2005

Harbani Pasolong. Teori Administrasi Publik. Alfabeta. Bandung. 2010

Keban, Y.T. 2008, Enam Dimensi Strategis Administrasi Publik: Konsep, Teori, Isu, Yogyakarta, Gava Media.

Kumorotomo Wahjudi, 2001, Etika Administrasi Negara, Raja Grafindo Persada, Jakarta

Lembaga Administrasi Negara (LAN) RI. 2000. Badan Pengawasan Keuangan dan Pembangunan (BPKP), pengukuran kinerja instansi pemerintah: Modul sosialisasi Sistem Akuntabilitas Kinerja Institut Pemerintah. Lembaga Administrasi Negara (LAN) RI

Levine Charles H., B. Guy Peters dan Frank J. Thomson (1990),, Public Administration; Challenge,Choices, Consequences., Illinois: Scott, Foremansilittle, Brown Higher Educatio

Miftah Thoha, 2005, Perilaku Organisasi: Konsep Dasar dan Aplikasinya,Jakarta, Raja Grafika Persada.

Mustopadidjadja AR 1999, Administrasi Pembangunan, Jakarta: Lembaga Administrasi Negara RI.

Ndraha, Taliziduhi. 2003. Budaya Organisasi. Jakarta: PT. RadjaGrafindo Persada

Ndraha, Taliziduhu. 1997, Metodologi Ilmu Pemerintahaan, Rineka Cipta, Jakarta

Onno Sahlania Hamzah. 2014. Perilaku Birokrasi Pemerintah Dalam Pelayanan Puskesmas Di Kota Makassar. Jurnal Administrasi Publik, Volume 4 No. 1 Thn. 2014

Pinto dalam Nisjar S.Karhi, 2001, Beberapa Catatan Tentang "Good Governance", Jurnal Administrasi Dan Pembangunan, Vol. 1 No. 2, 1997, Hal 119, Widodo, Good Governance, Surabaya: Insan Cendekia 
Quill, Lawrence. 2008. Ethical Conduct and Public Service: Loyalty Intelligently Bestowed. The American Review of Public Administration. Vol. 20, No. 10, hal. 1-10.

Riyaas Rasyid, 2000, Arah Kebijaksanaan Pemberdayaan Sumber Daya Aparatur Negara Yang Profesional Dalam Era Pembangunan Indonesia Baru, Makalah.

Robbins, S.P. dan Timothy A. J. 2008. Perilaku Organisasi. Penerjemah Diana Angelica. Jakarta: Salemba Empat.

Shafritz, Jay M. dan Russell, E.W. 1997. Introducing Public Administration. New York: Longman

Ted Gaebler and Peter Plastrik, 1997, Banishing Bureaucracy: The Five strategies, For Reinventing Government, Massachusetts: Addison - Wesley Mustopadidjaja AR,dkk, 1999, Administrasi Negara, Demokrasi dan Masyarakat Madani, Lembaga Administrasi Negara RI, Jakarta. 